\title{
Kropotkin's Theory of Mutual Aid in Historical Context*
}

\author{
RUTH KINNA
}

\begin{abstract}
Summary: This paper examines the relationship between science and anarchism in Kropotkin's theory of mutual aid and analyses it in the light of his concerns about the rise of social democracy and individualism. Tracing the development of the theory from the 1890s to Kropotkin's death in 1921, it affirms the centrality of mutual aid in his work but argues, contrary to existing readings, that the theory can be seen as an attempt to inspire the revival of the anarchist movement. It concludes that there is an unresolved tension in Kropotkin's work arising from the imbalance between the idea of a "natural anarchist tendency" and anarchist propaganda.
\end{abstract}

\section{INTRODUCTION ${ }^{1}$}

Kropotkin's first article on the theory of mutual aid appeared in September $1890 .^{2}$ By 1902 he had collected enough material to publish the

* This paper was prepared with the support of the British Academy and the Institute for Social History, Amsterdam. I would like to thank Vincent Wright, Keith Dowding and Mieke ljzermans for their support and Robert Knight, John Marks and two anonymous referees for comments on earlier drafts.

${ }^{1}$ The main conclusions drawn from this paper are in line with Michael Confino's and Daniel Rubinstein's recently published findings ("Kropotkine Savant: Vingt-cinq lettres inédites de Pierre Kropotkine a Marie Goldsmith 27 juillet 1901-9 juillet 1915", Cahiers du Monde russe et soviétique, XXXIII (1992), pp. 243-302) which was drawn to my attention after this paper was substantially completed.

${ }^{2}$ The complete range of articles comprising the theory of mutual aid was published in The Nineteenth Century as follows: "Mutual Aid Among Animals" part 1, XXVIII (1890), pp. 337-354; "Mutual Aid Among Animals" part 2, XXVIII (1890), pp. 699-719; "Mutual Aid Among Savages", XXIX (1891), pp. 538-559; "Mutual Aid Among the Barbarians", XXXI (1891), pp. 101-122; "Mutual Aid in the Mediaeval City" part 1, XXXVI (1894), pp. 183-202; "Mutual Aid in the Mediaeval City" part 2, XXXVI (1894), pp. 397-418; "Mutual Aid Amongst Modern Men", XXXIX (1896), pp. 65-86; "Mutual Aid Amongst Ourselves", XXXIX (1896), pp. 914-936; "The Ethical Need of the Present Day", LVI (1904), pp. 207-226; "The Morality of Nature", LVII (1905), pp. 407-426; "The Theory of Evolution and Mutual Aid", LXVII (1910), pp. 86-107; "The Direct Action of Environment on Plants", LXVIII (1910), pp. 58-77; "The Response of the Animals to Their Environment" part 1, LXVIII (1910), pp. 856-866; "The Response of the Animals to Their Environment" part 2, LXVIII (1910), pp. 1046-1059; "The Inheritance of Acquired Characters: Theorctical Difficulties", LXXI (1912), pp. 511-531; "Inherited Variation in Plants", LXXIV (1914), pp. 816-886; "Inherited Variation in Animals", LXXVIII (1915), 
book, Mutual Aid, for which he is probably best known. He continued to work on the project until his death in 1921 and later works like The State: Its Historic Role and Ethics should be considered as part of the project. $^{3}$

Most writers agree that Mutual Aid lies at the centre of Kropotkin's thought but they have had difficulty pinpointing its precise significance. Some place Kropotkin's theory in the framework of late nineteenthcentury positivist social science and view it as an attempt to chart laws of co-operation in human society based on Darwinian evolutionary theory. On this view Kropotkin's work appears to be connected to Spencer's and Comte's, though the connections are rarely made explicit. ${ }^{4}$ Others give more weight to Kropotkin's scientific motivation, sometimes to the point of distegarding the political component of his work. Daniel P. Todes, for example, argues that Kropotkin's concern with mutual aid pre-dates his conversion to anarchism and is independent of his later ideological interests. He presents mutual aid as a response to the Darwinian metaphor of "struggle" and argues that Kropotkin's conception was developed as a result of his immersion in Russian biological theory as well as of his own independent research. ${ }^{5}$

Neither of these readings seems entirely satisfactory. At the two extremes, the theory of mutual aid is either seen as a failed attempt to demonstrate a law of altruistic development or it is stripped of its political content altogether. Stepping between these positions, Mondolfo claims the theory both for anarchism and for biology but emphasizes the importance of Kropotkin's scientific discoveries. As a "Russian scientist, sociobiologist and anarchist" Kropotkin (Figure 1) "made important geographical and anthropological investigations, which led him to conclude that state action was ineffective while mutual aid was of greatimportancein thestruggleforexistence [. . . ]incontradiction tothe Hobbesian thesis of eminent Darwinists". ${ }^{6}$ Yet Mondolfo's circumspection

pp. 1124-1144; and "The Direct Action of the Environment and Evolution", LXXXV (1919), pp. 70-89. Hereafter, articles will be referred to by title only.

${ }^{3}$ See Max Nettlau, "Un Vie", in Pierre Kropotkine L'Ami, L'Homme, L'Anarchiste (Paris, 1921), pp. 6-7; and George Woodcock's introduction to The State: Its Historic. Role (London, 1943), p. 4, and Ethics: Origin and Development, trans. Louis S. Friedland and Joseph R. Piroshnikoff (Montreal and New York, 1992), p. xvii. Woodcock's views on the significance of Ethics for Kropotkin's work have changed considerably since the publication of Anarchism (Harmondsworth, 1975), where he claims it is a "peripheral" work, p. 198.

4 For a recent analysis see George Crowder, Classical Anarchism: The Political Thought of Godwin, Proudhon, Bakunin and Kropotkin (Oxford, 1991). See also my critique and following exchange in Anarchist Studies, 1 (1993), no. 1, pp. 51-59; no. 2, pp. 147-154.

3 Daniel P. Todes, "Darwin's Malthusian Metaphor and Russian Evolutionary Thought, 1859-1917", Isis, 78 (1987), pp. 537-551.

- Rudolfo Mondolfo, "Kropotkin, Prince Petr Alexeyevich", in E.R.A. Seligman (ed.), Encyclopedia of the Social Sciences, VII (London, 1930), pp. 602-603. 
leaves the relationship between the "political" and the "scientific" aspects of mutual aid unclear. In the following discussion I argue that political aspect was primary and suggest that Kropotkin's theory of mutual aid can be seen as an attempt to motivate action in the face of the decline of revolutionary anarchism. I also suggest that mutual aid does not describe a law of natural development but that Kropotkin's particular understanding of science and of Darwinian theory led him to believe that science could be used as a political instrument to halt this decline. To illustrate this point, I analyse the theory of mutual aid in relation to the rise of social democracy and individualism, two forces which Kropotkin came to see as the greatest threats to the anarchist movement in the 1890s.

\section{THE POLITICAL BACKGROUND}

The early years of the twentieth century were not happy ones for the English anarchist movement. In 1900, the anarchist newspaper Freedom reported that "for the last years the Labour Movement in this country has been going indifferently". Three years later the paper looked back "over "a quiet year for the English labour movement" and in 1905 it confessed that the previous year had left "a dull and dismal record for those who are concerned for the future of humanity".? Kropotkin was equally despondent. In 1904 he complained to Alfred Marsh, the sometime editor of Freedom, that "our movement just now is so slow, so low down". Things were not much better the next year and again he complained, "English life is so dull, so dull! [. . . I I find nothing that I might write about with interest". 8

The immediate cause of Kropotkin's malaise was the success of Marxism. This concern was hardly a new one; Kropotkin had always shown a deep-seated antipathy toward Marxism and its political strategies. His disagreement broadly followed the Bakuninist tradition, centring on the Marxist understanding of the state: during the 1870 s and $1880 \mathrm{~s}$, he stigmatized Marxists as jacobins and authoritarians and argued that their political strategy was a ploy to veil their dictatorial desires. However, towards the end of the 1880 s and the beginning of the 1890s his attitude became noticeably more intransigent. Though he avoided the antisemitism implicit in Bakunin's dismissal of Marx as a "German and a Jew" he began to display signs of germanophobia. As Justice noted sarcastically, "Marx has always been [Kropotkin's] special aversion. He was deep and he was German, and he fell out with Bakunin. Therefore Marx must be wrong". to For Kropotkin Marxism was "caesarism", a

Treedom, 146 (March-April 1900), 173 (January 1903), and 195 (January 1905).

Kropotkin to Alfred Marsh, 3 September 1904, 20 June 1905, International Institute for Social History [hereafter IISH], Marsh collection.

Michacl Bakunin, Statism and Anarchy, ed. Marshall Shatz (Cambridge, 1990), p. 141.

${ }^{10}$ Justice, "Kropotkin as Mock Bourgeois Radical" (March 1904). 


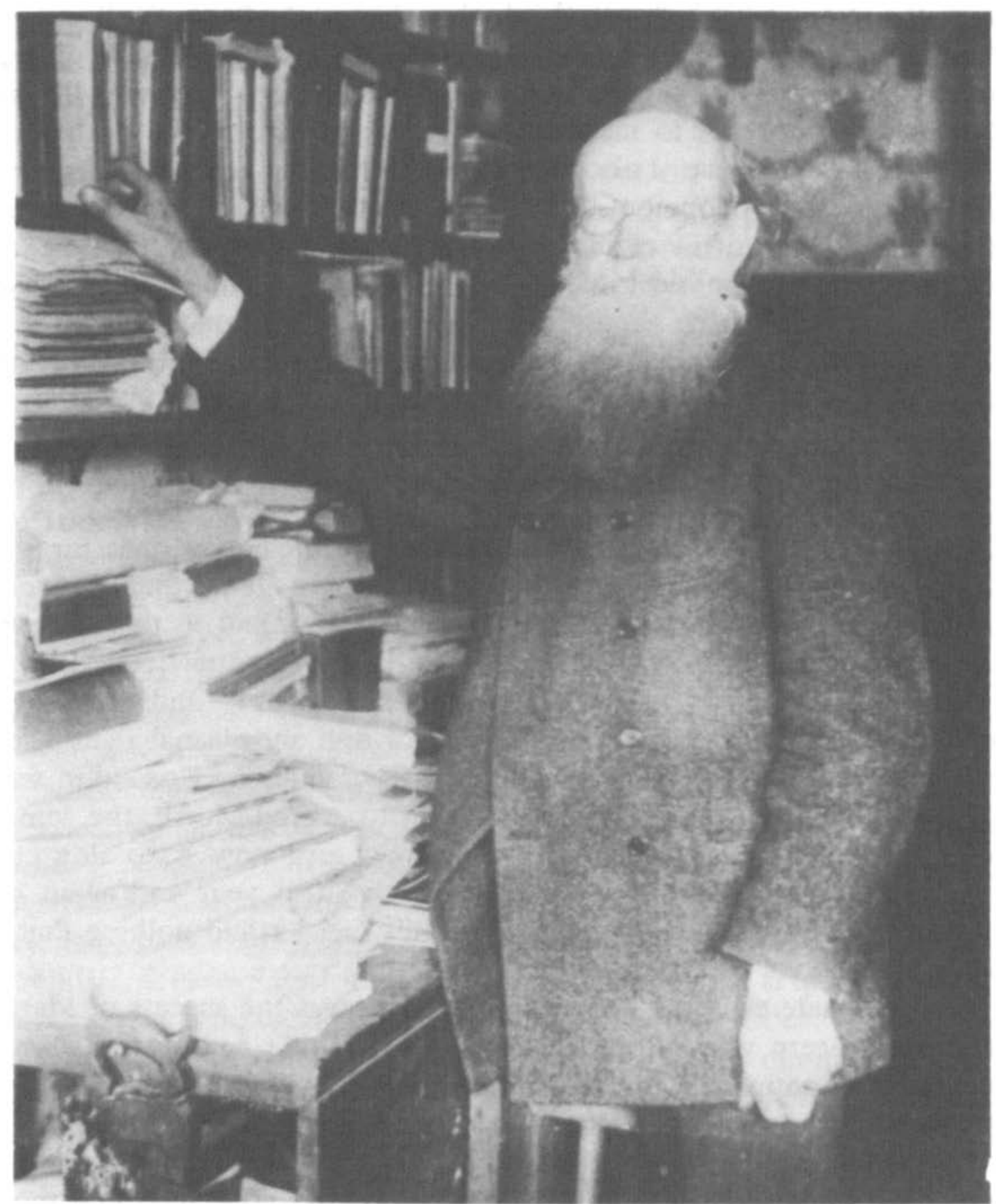

Figure 1. Kropotkin in his study in Brighton, 1911 (Photograph by Charlotte Roche. Collection IISG)

specifically Teutonic combination of authoritarianism and militarism. The crushing defeat of France in 1871, he argued, was "[t]he triumph of Germany and the triumph of militarism in Europe, of military and political despotism". The failure of the Paris Commune, in particular, signalled the victory of a disciplined and authoritarian German state against the spontaneous forces of the free Latin temperament. It meant that "the worship of the State, of authority and of State Socialism, which is in reality nothing but State capitalism, triumphed in the ideas of a whole generation"."

"Kropotkin, "Caesarism", Freedom, 139 (June 1899). 
Convinced that Germany had now become the dominant power in Europe, Kropotkin came to see that the chances of realizing significant revolutionary change had been dramatically diminished. Indeed, he grew increasingly certain that Europe would reach the point of war before it was ripe for revolution. In 1902 this was still only a vague fear ${ }^{12}$ but just two years later Kropotkin had become firmly convinced that the German and French governments had decided that war was inevitable and were only looking for a pretext to mount one. By 1913 he was not only certain that war was imminent but, much to the chagrin of the majority of his comrades, had reconciled himself to the need to support the Entente powers when it broke out. ${ }^{13}$

In part Kropotkin was led to this view by the series of diplomatic crises which unsettled Europe in the 1900s. But the point here is that he also believed that Marxism was partly to blame for the poor state of international relations. On the one hand, by its domination of the revolutionary movement Marxism had weakened the resistance of the workers to the appeals of European state imperialism. In England, for example; Marxism "has done more to give a free hand to the Imperialist than anything else". ${ }^{14}$ On the other, where the population remained resistant to jingoistic propaganda, Marxism threatened the potential of burgeoning revolutionary movements. If Marxism were to succeed in Russia, for example, Kropotkin warned that it would lead to the abolition of the village commune and the destruction of the peasantry, two of the most important pillars of the movement. This might satisfy the conditions laid down by Marxist dogma, but it would leave the European revolutionary movement further weakened. ${ }^{25}$

Kropotkin's hardening attitude towards Marxism can be seen in his changing view of the British socialist movement and H.M. Hyndman's Social Democratic. Federation in particular. During his year of exile in London Kropotkin had been broadly sympathetic towards the SDF. According to his memoirs, he thought Hyndman's England For All an "excellent exposition of Marxist socialism" and remembered that in 1882 he "earnestly [advised] him to start a socialist paper". ${ }^{16}$ His views remained unchanged on his return to England in 1886, "the year when [. . . ] a most enthusiastic Socialist movement was going on [. . .]" - a movement directed towards the Social Revolution. ${ }^{17}$ Even though Kropotkin thought the SDF was following a flawed ideology, it was still behaving as a revolutionary party, organizing "large popular

12 Kropotkin to Marsh, 27 May 1902, IISH, Marsh Collection.

13 Kropotkin to Georges Herzig, 3 June 1913, IISH, Herzig Collection.

${ }^{14}$ Kropotkin to Marsh, 15 October 1901, IISH, Marsh Collection.

is Kropotkin to James Guillaume, 23 December 1902, IISH, Nettlau Collection, 293, KVI.

${ }^{26}$ Kropotkin, Memoirs of a Revolutionist (London, 1978), p. 300.

$"$ Kropotkin, Glimpses into Labour Movement MS, IISH, Nettlau Collection, 290, KIV, pp. 4-5. 
demonstrations which found a wide response". ${ }^{18}$ Asked by Hyndman for his opinion on the SDF, Kropotkin told its leader that the party was "delightful". ${ }^{19}$

But the flirtation did not last long. The SDF would not be shifted from Marxism and by 1890 Kropotkin felt that the socialist movement as a whole had become positively hostile to anarchism. In England, Kropotkin noted, "the mass of the [. . . ] working men" failed to discuss properly "the principles of Socialism, Collectivism, Communism, Mutualism [and] Anarchism". As in Germany the "Marxist expression was taken over as faith". ${ }^{20}$ By the turn of the century Kropotkin was arguing that the SDF's capitulation to the blinkered forces of the German ideology had been inevitable: the "English Socialists [had] got their Socialist education from the German Socialists [.. .] and after a time [they] returned under the same influence once more". ${ }^{21}$

The anti-German bias of Kropotkin's later perception of Marxism sometimes borders on the pathological. But it also reflects historical developments in international working-class organization. By the 1890s Marxists had for the first time begun to organize mass working-class parties and to adapt Marxist theory to social democratic practice. For Kropotkin, the realization by Marxism of its organizational potential meant that it was no longer simply an ideological threat: it had become a serious counter-revolutionary force. The largest and most disciplined example of this change, the German Social Democratic Party, confirmed Kropotkin's worst fears about "Teutonic domination". Not only did the SPD serve as a model for other social democrats to emulate, it also exercised a guiding influence in the affairs of the Second International and ensured that all socialist parties followed its line of "political action".

The most bitter battles over political action were fought between 1889 , when the International was founded, and 1896, when the anarchists were finally banned from attending its congresses. Kropotkin took an active part in these clashes and placed his rejection of political action at the heart of his anti-Marxist campaign. Political action represented "a submissive acceptance of the capitalist exploitation, with but a few limitations carried from time to time by a capitalist legislation against its worst offensive forms". ${ }^{22}$ Carefully distinguishing socialism from social democracy he described the latter as "an occasional patching up, by means of bureaucratic parliamentary legislation, of a few of the most crying injustices from which labour is suffering; a picking up, out of the masses of the workers, of the few of those who render themselves acceptable to the bourgeoisie, and are ranged in its ranks; a truce

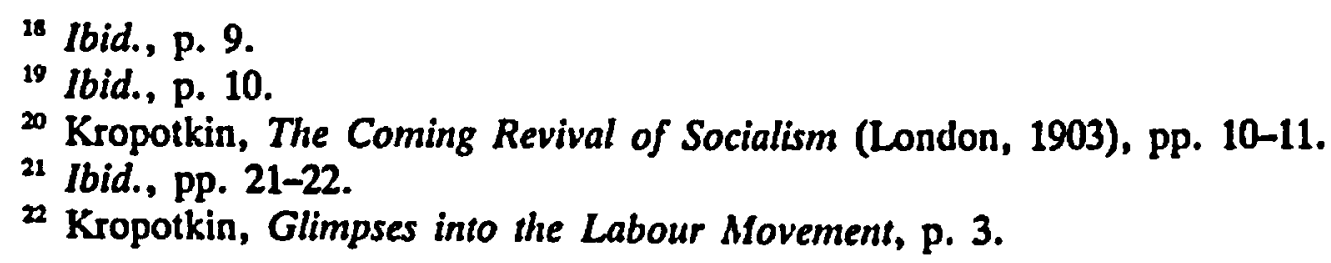


between the representatives of the exploited workers and the exploiters, on the understanding that both of them shall exploit for their common benefit the black and yellow races". ${ }^{23}$

Political action not only implied the acceptance of parliamentary forms, it also required the pursuit of a strictly constitutional policy. For Kropotkin, this restriction was inevitable since extra-parliamentary action by workers acting for themselves threatened the chances of those "opportunists" who wished to pursue a parliamentary career. It made them appear "anti-system" and attracted the disapproval of those political opponents who would later become parliamentary colleagues. Yet for the workers, Kropotkin argued, political action actually reduced the chances of achieving improvements within the existing system. Recalling the first demonstration for the eight-hour day in May 1890, he notes, "we surely would have been in a fair way towards the realisation of that demand, were it not for the political Socialists who saw in the eight hours movement a plank to step on for getting into Parliament". They did their best "to nip the movement in the bud" and were terrified "lest the eight hours movement should become a labour movement, over which they had no control [... .] and they hammered into the workers' heads, 'legal eight hours! legal eight hours!'".24

Whilst Kropotkin was concerned with political action because of its practical effects, his critique also went to the very heart of social democratic thinking. He saw the strategy as the necessary outcome of a fundamentally flawed theory. The root of the problem lay in Marx's claims to have founded "scientific socialism". From Kropotkin's point of view, the claim was absurd and he told James Guillaume that Marx's "science", largely borrowed from Adam Smith, would make any mathematician laugh. ${ }^{25}$ In a similar vein, whilst he conceded that Capital was necessary reading matter for a German audience, and a "formidable revolutionary pamphlet" [!] he argued that it was greatly overrated. ${ }^{26}$ If it was science at all, Marxism was a "science worked out to support all round compromise". ${ }^{27}$ Elite political bargaining was its almost inevitable consequence. Based on an unsubstantiated set of beliefs about dialectical laws of development its chief discovery was the "law of 'self-annihilation' " according to which the masses were assured that the revolution would come about without their active participation. Sarcastically, Kropotkin parodied the Marxist appeal to the workers thus:

Vote! Greater men than you will tell you the moment when the self-annihilation of capital has been accomplished. They will then expropriate the few usurpers

23 lbid., p. 2.

24 Kropotkin, "Politics and Socialism", Freedom, 176 (May 1903).

${ }^{25}$ Kropotkin to Guillaume, 23 December 1902.

${ }^{26}$ Kropotkin to Guillaume, 5 May 1903, IISH, Nettlau Collection, 293, KVI.

${ }^{27}$ Kropotkin, Glimpses into the Labour Movement, p. 4. 
left, who will own everything, and you will.be freed without ever having taken any more trouble than that of writing on a bit of paper the name of the man whom the heads of your faction of the party told you to vote for ? $^{28}$

By the turn of the century Kropotkin had become resigned to the Social Democrats' onward march in the International. But he remained committed to the task of constructing an alternative socialist movement and to building a secure base for anarchism amongst the workers. As part of this campaign, he wrote a series of articles to show that Marxism was only one of several strains of European socialist thought and the least important, at that. Owen, Fourier and Proudhon were the true fathers of the socialist movement and it was their ideas which had pervaded the First International until it had been captured by Marx, who then perverted it for his own ends. ${ }^{29}$ Kropotkin's view that the original goals of the International could only be achieved by independent workers' organizations drew him towards syndicalism. At the same time this interest in working-class organization confronted him with a number of problems, including the nature of the relationship between anarchism and syndicalism and the seemingly innate reformism of the workers. Most importantly, it forced him to reflect on the anarchist movement itself and the nature of its revolutionary commitment. He became suspicious that the anarchist movement had lost its sense of direction and located the reason in its growing obsession with "individualism".

Kropotkin's concern with individualism, like his fear of Marxism, was long-standing. In his early writings, he had looked at the problem in a variety of ways. The Conquest of Bread, for example, presents a critique of "economic" individualism, the idea that individuals are independent producers who ought to be rewarded as such. In part, Kropotkin takes a conventional line and associates economic individualism with laissezfaire. He suggests that the "development of Individualism during the last three centuries is explained by the efforts of the individual to protect himself from the tyranny [...] of the State". ${ }^{30}$ Less conventionally, he defines individualism as a commitment to certain overriding goals: economic individualism, he argues, implies a primary adherence to values of production rather than consumption. This definition allows him to see laissez-faire as only one form of economic individualism - that associated with political liberalism - but at the same time to define "economic individualism" as the collectivist principle of distribution according to work, and thus link it with Marxism. However, Kropotkin makes clear that Marxist and liberal doctrines of economic individualism have different theoretical roots: laissez-faire liberalism is tied to a misconceived notion of the individual whilst Marxist collectivism is rooted in

28 Kropotkin, Freedom, 175 (April 1903).

${ }^{29}$ See, for example, Kropotkin, The Development of Trade Unionism (Leeds, 1901).

${ }^{30}$ Kropotkin, The Conquest of Bread (London, 1983), p. 46. 
a faulty sociological approach, which leads it to disregard individual needs and instead focus on the needs of the state.

For Kropotkin anarchism is also individualist but he distinguishes it from liberal and Marxist individualism both in its foundational assumptions and in its goal. Anarchist individualism rejects the liberal idea of the individual whose needs can be met independently of society. The liberal reasons mistakenly that "'[b]y means of money [. . . I I can buy all that I need." But, Kropotkin responds, "modern history has taught him to recognize that, without the help of all, he can do nothing, although his strong-boxes are full of gold". 31 Yet anarchist individualism does not deny the existence of the individual altogether and, against Marxist-individualism, Kropotkin argues that the proper method of social inquiry is to start "from a free individual to reach a free society" rather than "beginning by the State to come down to the individual". ${ }^{32}$ Finally, against both liberal and Marxist versions of economic individualism, anarchist individualism aims at the satisfaction of individual needs rather than the fulfilment of production values. Kropotkin summarizes his position thus:

if the needs of the individual are taken as the starting-point of our political economy, we cannot fail to reach Communism, an organization which enables us to satisfy all needs in the most thorough and economical way. While if we start from our present method of production, and aim at gain and surplus value, without asking whether our production corresponds to the satisfaction of needs, we necessarily arrive at Capitalism, or at most at Collectivism - both being but two different forms of the present wages system. ${ }^{33}$

Kropotkin recommends anarchist individualism on the grounds that it leads to the full development of the individual whilst also creating strong communal bonds between individuals. "As soon as [. . . ] material wants are satisfied", he argues, "other needs [... . of an artistic character, will thrust themselves forward. These needs [...] vary with each [...] individual; and the more society is civilised, the more will individuality be developed, and the more will desires be varied."34 Because it leads to communism and to satisfaction of need, it encourages individuals to think of the needs of others and to share goods in common. Even though liberals and Marxists also claim to support individuality, as advocates of economic individualism they cannot provide the conditions for its fulfilment. Indeed, both destroy the necessary basis of sociability. Liberals overlook both the social and material needs of the individual and their version of economic individualism furthers self-interest, breaks down the moral ties of the community and fosters a morality based on

\footnotetext{
38 Ibid., p. 47.

32 Ibid., p. 174.

${ }^{33}$ lbid., p. 179.

Ibid., p. 108.
} 
the calculation of individual advantage. ${ }^{35}$ Marxists for their part satisfy material needs but do so only by swamping the individual by the state. Moreover, the primacy they give to the needs of the state leads them to adopt a collectivist principle, of distribution according to work, which gives a "narrowly egoistic turn [.. .] to men's minds". ${ }^{36}$ This form of economic individualism gives "too much to counting". It has become "influenced into giving only to receive" in the hope of "turning society into a commercial company based on debit and credit". ${ }^{37}$

Despite his long-standing concern to distinguish anarchist from liberal and Marxist conceptions of individualism, Kropotkin was not particularly worried about the issue until the turn of the century when his fear of the growing popularity of Nietzscheanism brought it into sharp focus. On occasions, Kropotkin discussed Nietzscheanism as if it were synonymous with "egoism" and he linked it to Mandeville's Fable of the Bees, as a facet of liberal individualism. Describing the doctrine as "miserable, petty and low", he considered its concept of individuality as essentially bourgeois. In a letter written in February 1902 to Max Nettlau, for example, he reconsidered the possible development of the future anarcho-communist society, obliquely referring to Nietzsche's "blond beasts":

Je crois que la communisme passera à l'état d'habitude (il l'est déà pour mille choses), et quant à savoir en quoi consistera l'essence de développement individuel, je ne crois pas qu'il puisse être individualiste. Individuel - oui, sans doute, mais individualiste - j'ai doute. Ceci signifierait: etroit égoísme $=$ évolution régressive, et par cela même serait limité à un certain nombre des "bêtes blondes" ou noires. ${ }^{38}$

Kropotkin clearly also believed that Nietzscheanism embodied a new, worrying manifestation 'of individualism. He described Nietzschean thought as "sensual" and Romantic. Tracing its roots to Byronic thought, he argued that it sought to liberate the individual by effecting an escape "from the notion of good and evil" and by giving free reign to the passions. Nietzscheans, Kropotkin believed, wrongly defined individual freedom in opposition to the community, which they saw as the upholder of indefensible boundaries of permissible action. They not only overlooked the possibility of reconciling the individual with the community

3s See, for example, Kropotkin, The Place of Anarchism in Socialistic Evolution, trans. H. Glasse (London, 1886).

${ }^{36}$ Kropotkin, The Conquest of Bread, p. 47.

${ }^{37}$ Ibid., p. 171.

${ }^{38}$ Kropotkin to Max Nettlau, 17 February 1902, IISH, Nettlau Collection, 287, KI, "I think that communism will become quite normal (it is already in a thousand ways), and as for knowing what will be the essence of individual development, I do not think it could be along individualist lines. Individual - yes, without doubt, but individualist - 1 have my doubts. That would mean: narrow egoism = regressive evolution and even that would be limited to a certain number of 'blond beasts' or black ones". 
but, in elevating the inner sentiments of particular individuals to the status of moral principles, Nietzscheans espoused a philosophy which was consistent with the slavery and oppression of the masses. ${ }^{39}$

Kropotkin's response to Nietzscheanism seemed to reverse his earlier position on anarchist individualism. He now attempted to demonstrate that anarchist individualism was compatible with self-interest and argued that individuals were psychological egoists, driven by desires and aversions beyond their wilful control. In Anarchist Morality, for example; he suggested that "whatever a man's actions and line of conduct may be, he does what he does in obedience to a craving of his nature [...] Let him act as he may, the individual acts as he does because he finds a pleasure in it, or avoids [. . .] a pain." ${ }^{\prime 40}$ It might be asked why these drives fail to impoverish communal relations in the same way that Kropotkin had earlier argued liberal individualism does. Kropotkin's answer is flatly to deny the possibility of unsociability; by definition what gives pleasure to the individual is the community and what gives pain is harming it. Thus even before Man Friday appeared, Robinson Crusoe had his animals to think of. He "had to think of the interests of others, he was no longer the perfect individualist". Likewise, "[m]an takes and will always take into consideration the interests of other men in proportion to the establishment of relations of mutual interest between them, and the more so the more these others affirm their own sentiments and desires." $" 41$

Kropotkin explained the appeal of Nietzscheanism in a number of ways. He told his friend, the critic Georg Brandes, that it was because a generation of Scandinavians had suffered from a doctrinaire system of Protestant education that they mistakenly believed Nietzsche's individualism to be liberating. ${ }^{42}$ In France, he suggested that interest in Nietzsche's work had come at a time of general political instability and when, furthermore, the success of Marxism and the strength of the parliamentary movement had led some anarchists to believe "that the heroic acts of a little handful of men would be enough to rouse the people into insurrection and to demolish the fortress of the old regime". ${ }^{43}$ Taken together, these factors had provided a particularly fertile soil for the spread of Nietzschean amoralism.

Kropotkin's concern with Nietzscheanism was essentially practical. $\mathrm{He}$ believed that it had become fashionable in some sections of European society, particularly in France, and that it threatened to envelop anarchist supporters. Though in the French context Kropotkin accepted that some

${ }^{39}$ Kropotkin to Guillaume, 12 June 1903, IISH, Nettlau Collection, 293, KVI.

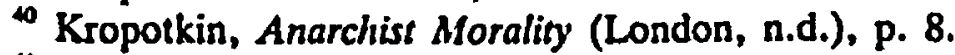

41 Kropotkin, "Communism and Anarchy", part 2, Freedom, 159 (August 1901).

${ }^{2}$ Kropotkin to Georg Brandes, 20 March 1903, Correspondance de Georg Brandes II, ed. Paul Kruger (Copenhagen, 1956), p. 179.

${ }^{43}$ Kropotkin, "Enough of Illusions", Freedom, 220 (August 1907). 
anarchists were motivated by a genuine revolutionary spirit and that they were not in fact acting as Nietzschean individualists, he also argued that their activities had become popular with the children of the bourgeoisie and that this support had led them astray. Egged on by Nietzscheans, French anarchists had become unwittingly involved in an escalating campaign of terrorism. In the end anarchism suffered since the state responded in kind by unleashing unprecedented repressive force against the terrorists, and as a result, potential supporters were alienated from the cause. ${ }^{44}$

Kropotkin concluded from the French experience that anarchism could only lose from an association with Nietzscheanism and that the temptation for anarchists to try and exploit its popularity had to be resisted. Instead anarchists should embark on a long-term policy of education and propaganda which would make anarchism as popular as Nietzscheanism. Above all they should recognize that the ground for all previous revolutions had been prepared by the gradual spread of ideas. ${ }^{45}$ It was as a contribution to this process that Kropotkin saw his theory of mutual aid.

\section{THE EVOLUTION OF MUTUAL AID}

How was the theory of mutual aid to help prepare the ground for a revival of revolutionary anarchism? In general terms the answer lies in Kropotkin's understanding of the role and the history of science. Its role was to serve both as a means of understanding the natural world and as the foundation of real knowledge. In this sense it was an instrument of human education and liberation, "the supreme authority" and the "expression and the revelation" of truth. ${ }^{46}$ Kropotkin's interpretation of its history was more complex. He suggested that mankind had become somehow separated from the truth vested in science and that as a result its educational value had been diminished. As he noted in his essay, "On the Teaching of Physiography",

Natural sciences, it is said, do not give to education the human character they ought to give. This is true; and the objection remains in full force until now. However, it depends entirely upon ourselves to make of these a most powerful instrument for conveying human education as well [ . . . [. ${ }^{47}$

For Kropotkin, science could be restored to its full potential only if the separation of its natural and human aspects could be reversed. This

4 See Kropotkin's letters to Nettlau, 17 February and 5 March 1902, IISH, Nettlau, 287.

"s See, for example, Kropotkin, "The Great French Revolution and Its Lesson", The Nineteenth Century, XXV (1889), pp. 838-851.

${ }^{46}$ Kropotkin quoting Francisco Ferrer, "Speech at the Ferrer Meeting", Memorial Hall, 21 October 1909, MS, IISH, Nettlau, 290, KIV.

${ }^{47}$ Kropotkin, "On the Teaching of Physiography", from the Geographical Journal (October 1893), p. 5. 
dissolution had been caused by the development of natural and human sciences along two distinct methodological routes. Where the natural sciences had rightly been studied by the "inductive-deductive" method, the human sciences had, improperly, been examined by "metaphysics". This methodological specialization, Kropotkin believed, had wrongly encouraged theorists to consider the subject matter of the natural and of the human sciences to be entirely different and to have seen two worlds in a spurious polarity. On the one hand, natural scientists had come to conceive of human progress as a movement away from nature and to see human societies as essentially artificial constructs designed to remove mankind from its "natural" state. On the other hand, human scientists had understood mankind's place in the natural world but had considered this to be in opposition to science. Tolstoy, for example, had been "possessed of the most scientific insight" and had formulated principles which were "true", but they could not be known to be true because of his "distrust of science". 48

Kropotkin argued that this separation of the natural from the human sciences had not always existed: the ancient Greeks, he noted, "did not separate man from Nature". The "divorce between human sciences history, economy, politics, morals - and the natural sciences has been accomplished entirely by ourselves, especially during our century [. . .]." ${ }^{49}$ The newness of the divide meant that there was every chance that it could be healed.

To mend the break in part required the consistent application of the inductive-deductive method to the human sciences. ${ }^{50}$ There was no reason, he insisted, why it should be abandoned in favour of metaphysics "when we pass from the flower to man, or from a village of beavers to a human city". ${ }^{\text {st }}$ But Kropotkin also argued for an evolutionary perspective. This would not only chart the progress that the human sciences had made hitherto but also give them the natural scientific backing that they had previously lacked. In developing this argument he claimed that he was following "the course traced by [the] modern philosophy of evolution" elaborated by Comte and Spencer. ${ }^{32}$ Yet Kropotkin did not simply see himself as a positivist since he thought that the positivists had also, in their own way, fallen foul of the methodological divide and this had led them to purge their work of the human scientists' philosophical insights. Comte, for example, had failed to consider that the "moral

\footnotetext{
48 Kropotkin, Ideals and Realities in Russian Literature (New York, 1916), p. 69.

49 Kropotkin, "Teaching of Physiography", p. 6.

${ }^{30}$ The inductive-deductive method combines primary observations with explanatory hypotheses which are then tested against further observations. For a description see Kropotkin, Memoirs, pp. 163-164.

S1 Kropotkin, Moderm Science and Anarchism (London, 1912), p. 40.

${ }^{52}$ Kropotkin, "The Scientific Bases of Anarchy", The Nineteenth Century, XXI (1887), p. 238.
} 
sense of man, like sociability and society itself, had a pre-human origin". ${ }^{33}$ Spencer, on the other hand; had succumbed to his conservative prejudices and failed to "fully endorse all the conclusions which ought to be drawn from his system of philosophy". ${ }^{54}$ His findings had been subordinated to his acceptance of the political status quo.

For Kropotkin, the reintegration of the human with the natural sciences depended on understanding the dual "tendencies" of the natural world: the movement "towards integrating our labour for the production of all riches in common" and the development "towards the fullest freedom of the individual for the prosecution of all aims [...]".ss Together, these tendencies amounted to the movement of mankind towards anarchy. In the past, this movement had been obscured by the artificial separation of the human and natural sciences. Now, Kropotkin proposed to demonstrate its reality by returning to "the Greek spirit which conceived man as a part of the Cosmos, living the life of the whole, and finding his greatest happiness in living that life". .6

Overcoming the artificial methodological divide between the human and natural sciences thus led to an anarchist conclusion. It also allowed Kropotkin to maintain two seemingly incompatible positions. On the one hand, in positivist terms, he described anarchism as "a conception of the Universe based on the mechanical interpretation of phenomena, which comprises the whole of Nature, including the life of all human societies and their economic, political, and moral problems". ${ }^{57}$ But on the other, he sought to correct what he thought to be the philosophical shortcomings of the positivists and argued, rather confusingly, that anarchism "does not draw its origin from any scientific researches, or from any system of philosophy". In common with "all other social movements, [it] originates among the people, and [.. . ] will preserve its vitality and creative force so long only as it remains a movement of the people". ${ }^{58}$ Kropotkin's belief in the unity of the natural tendency for anarchy and his desire to reveal its scientific integrity led him to study a variety of subjects including anthropology, geography and physics. Above all it led him back to biology and it was his biological research, expressed in the theory of mutual aid, that formed the centrepiece of his scientific and educational programme.

In his memoirs Kropotkin traces his introduction to biology to his childhood when he was apparently alerted to pre-Darwinian theories of transmission" $^{39}$ and realized that "Darwin with his Origin of Species,

\footnotetext{
${ }^{33}$ Kropotkin, Modern Science, p. 20.

s4 Kropotkin, "Scientific Bases", n. 1; p. 244.

ss Ibid., p. 239.

${ }^{36}$ Kropotkin, "Teaching of Physiography", p. 6.

s7 lbid., p. 38.

s8 Kropotkin, Modern Science, p. 1.

39 Kropotkin, Memoirs, p. 81.
} 
revolutionized all biological sciences".$^{60}$ His first practical experience of biology.came after his graduation from the elite military academy, the Corps of Pages, when in 1862 he joined a detachment of Cossacks -and started a posting in Siberia. The most important aspect of this five-year stay was that it confirmed Kropotkin's belief in the correctness of Russian interpretations of Darwinian theory.

From the start Russian scientists had been critical of Darwin and, in particular, had attacked his assimilation of Malthus' Essay on Population. ${ }^{61}$ Much of their initial criticism was politically motivated: they found the Darwinian metaphor of "struggle" offensive because it introduced into biology an idea of competition derived from "soulless" market society. This model, based on Malthus' famous principle of the geometric increase of population, was considered by both conservatives and radicals alike to be corrupting and iniquitous. Darwin's theory, his critics claimed, was incompatible with Russia's national destiny, which was variously defined as the salvation of the national soul or socialist liberation. ${ }^{62}$ Aside from these political objections, Russian biologists also criticized Darwin's definition of "struggle" as being too narrowly focused on competition between individuals. They saw few signs of individual competition within species. Indeed, when they looked at the vastness of Russia and the abundance of its resources they concluded that natural factors like climate limited population growth. In short, Russian evidence suggested that the struggle for existence was not necessarily a struggle for individual advantage within species but that it involved co-operation against the environment. ${ }^{63}$

Kropotkin was impressed by these arguments and in particular by the writings of the former Dean of St Petersburg University, Karl Kessler. In 1880 Kessler had delivered a lecture suggesting the importance of co-operation in the evolutionary process, which Kropotkin acknowledged in his introduction to Mutual Aid. Another important influence was biologist Severtsov, ${ }^{6+}$ who had been present at Kessler's lecture of 1880 and had supported his symbiotic thesis. Kropotkin described Severtsov as "one of the most intelligent men I ever came across"'ss and was clearly impressed by the reports he had made about "the importance

${ }^{50}$ lbid., p. 93.

${ }^{61}$ For an examination of nineteenth-century Russian biology see Francesco M. Surdo and Michele Acanfora, "Darwin and Russian Evolutionary Biology", in David Kohn (ed.), The Darwinian Heritage (Princeton, 1985), pp. 731-749; James Allen Rogers, "The Reception of Darwin's Origin of Species by Russian Scientists", Isis, 64, 224 (1973), pp. 484-504, and "The Russian Populists' Response to Darwin", Slavic Review, 22 (1963), pp. 456-468.

Q2 Todes, "Darwin's Malthusian Metaphor", pp. 538-542.

as Ibid., pp. 542-545.

*f An account of Severtsov's contribution to Russian biology is given in Alexander Vucinich, Science in Russian Culture 1861-1917 (Stanford, 1970), pp. 294-295.

os Kropotkin, Memoirs, p. 165. 
of mutual support in the progressive development of species [. . .]". Although in his memoirs Kropotkin admits that these reports. were "sketchy" in Mutual Aid he nevertheless calls Severtsov's observations "conclusive". .6

One likely reason why Kropotkin was so impressed with the Russian biologists' hostility to the Malthusian assumptions of Darwin's work was that, after his conversion to anarchism in 1874, it neatly dovetailed with his political ideas. It was a central assumption of Kropotkin's anarchism that scarcity could be overcome. Achieving abundance not only provided the material conditions for the development of anarchist individuality, it also bolstered his claim that distribution according to need could be operated without a centralized administrative system, on the basis of local self-sufficiency. If production were suitably reorganized, Kropotkin argued, small-scale communities could easily meet all their local economic needs. Just as it had undermined Godwin's anarchism in the 1820 s, Malthus' argument that population growth would always outstrip production was an obstacle to this view. Kropotkin understood the threat; as early as 1887 he tried to reverse Malthus' findings: "the available amount of means of subsistence increases at a rate which increases itself in proportion as population becomes denser - unless it be artificially [...] checked by some defects of social organization". ${ }^{67}$ Later on, he clung to his belief that an integrated economy based on industrial decentralization and agricultural reorganization could overcome scarcity and hence lead to anarchy. Kropotkin was unyielding on this point and ignored the criticism of both Malthusians and Fabians against him. ${ }^{68}$ He even chided the neo-Malthusian Paul Robin for campaigning in favour of the use of contraception. Population control, he argued, was a palliative measure dealing only with a biological symptom of a problem which was not biological but economic. If production were organized properly, reproduction need not inevitably lead to misery. ${ }^{69}$

The second reason for Kropotkin's preference for the "Russian" critique of Darwinian theory was that it could be used as a tool to forge the unity between the natural and the human sciences and thus as a means to disclose the world's "natural tendency" towards anarchy. He began to think about this project during the course of his imprisonment in Clairvaux ${ }^{70}$ and after his release in 1886 he started research. Two years later his ideas were galvanized by the publication of T.H. Huxley's

${ }^{66}$ Kropotkin, Memoirs, p. 165 and "Mutual Aid Among Animals", pp. 348-349.

67 Kropotkin, "Scientific Bases", p. 246.

6s See Kropotkin, Fields, Factories and Workshops (London, 1913); and for a response, C.V. Drysdale, Can Everyone Be Fed? A Reply to Prince Kropotkin (London, 1913); and William Clarke, "Industrial", in George Bernard Shaw (ed.), Fabian Essays, 6th ed. (London, 1962), pp. 94-134.

${ }^{69}$ Kropotkin to Robin, 31 August 1879, IISH, Nettlau Collection, 293, KVI.

${ }^{70}$ Kropotkin, Memoirs, p. 335. 
essay "The Struggle for Existence". This work prompted Kropotkin to add yet another layer to his project and "to put in a readable form my objections to his way of understanding the struggle for life [...]". ${ }^{71}$

Kropotkin's initial critique of Huxley was in line with the Russian tradition. He accused Huxley of wrongly characterizing the natural world as one of unremitting violence. Whilst acknowledging that Huxley was "one of the ablest exponents of the theory of evolution" Kropotkin still denounced his account of the natural world as "atrocious".

[Huxley] reduced the notion of the struggle for existence to its narrowest limits [. . . ] came to conceive the animal world as a world of perpetual struggle among half-starved individuals [...] made modern literature resound with the war-cry of woe to the vanquished, as if it were the last work of modern biology [...] [and] raised the "pitiless" struggle for personal advantages to the height of a biological principle which man must submit to as well, under the menace of otherwise succumbing in a world based upon mutual extermination. ${ }^{72}$

Kropotkin's critique traced Huxley's failure to his misinterpretation of Darwin's concept of "struggle". In the Origin of Species, Kropotkin rightly pointed out, Darwin uses the term in a wide "metaphorical" sense to imply the existence of co-operation as well as competition. To illustrate his point Darwin concedes that in extreme climatic conditions individual competition for scarce resources gives way to a "struggle for life which is almost exclusively with the elements". ${ }^{73}$ The illustration perhaps reinforced Kropotkin's own experiences of the natural world. But, in any case, he made full use of the concession and, ignoring Darwin's insistence that the narrower, competitive definition of the term "struggle" has a general application, he suggested that Huxley had made the mistake in believing individual competition to be the rule. Huxley's error, he contended, lay in his acceptance of "the narrow Malthusian conception of competition between each and all". ${ }^{74}$

Specifically, Kropotkin questioned Huxley's statistical assumptions and argued that population increases are limited by environmental factors, which mitigates the need for individuals to compete with one another. Furthermore, he claimed that members of species positively co-operate to overcome scarcity and thus to eliminate the need to compete. ${ }^{75}$ Clearly, these arguments are not completely compatible: after all, if numbers are kept down by natural constraints then there should be no competition in the first place. Kropotkin tried to avoid the contradiction by suggesting that only where environmental factors have not intervened

\footnotetext{
"Ibid., p. 336.

2 Kropotkin, "Mutual Aid Among Animals", pp. 338-339.

3 Charles Darwin, The Origin of Species (New York, n.d.), p. 56.

${ }^{74}$ Kropotkin, "Mutual Aid Among Animals", p. 338.

${ }^{75}$ Kropotkin, Mutual Aid: A Factor of Evolution (Boston, n.d.), pp. 72-75 and appendix VI.
} 
to keep populations in check do species need to adapt to circumstances and find alternative means to avoid competition. But as a general rule he suggested that nature's message is clear: "'Don't compete! - competition is always injurious to the species, and you have plenty of resources to avoid it!' That is the tendency of nature, not always realized in full, but always present." "76

After the publication of Mutual Aid in 1902 Kropotkin extended his initial critique of Huxley. He now charged him with wrongly suggesting that nature did not provide a basis for morality. Assuming that nature was "red in tooth and claw" Huxley had argued that it did not provide a basis for ethical behaviour. He had distinguished between natural non-ethical and civilized ethical man and argued that whilst the former had played out the "ape and tiger" methods of survival, only the latter had worked to counter the natural fight." Kropotkin dismissed this distinction and accused Huxley of denying the principles which he himself had shown to be the basis of evolution and of making unwarranted resort to metaphysical explanation: if "the only lesson Nature gives to man is one of evil, then [Huxley] necessarily has to admit the existence of some other, extra-natural [...] influence which inspires man with conceptions of "supreme good"". But this "nullifies his own attempt at explaining evolution by the action of natural forces only". In Kropotkin's view, Huxley's ethical position was bound to lead him back to religion, and in particular, to Christianity. ${ }^{78}$

To counter Huxley's argument, Kropotkin renewed his attack on his Malthusian premises which, once again, he saw as the most serious obstacle for the acceptance of his own theory. As he wrote in 1904,

There is not the slightest doubt that the hesitation of many biologists to recognise [...] mutual aid as a fundamental feature of animal life is due to the contradiction they see between such a recognition and the very hard Malthusian struggle for life which they consider as the very foundation of the Darwinian theory of evolution. ${ }^{\text {9 }}$

Kropotkin now sought to remove Malthus from Darwinian theory by showing that late in his life Darwin had revised the hypothesis of natural selection in favour of the Lamarckian principle of the direct action of the environment. For Kropotkin, this shift did not detract from Darwin's genius as a scientist but it did mean that his theoretical premises were shaky. Darwin himself, he claimed, had offered natural selection "as a working hypothesis only" which "had to be tested before it should be

76 lbid., p. 75.

$\pi$ T.H. Huxley, "The Struggle for Existence: A Programme", The Nineteenth Century, XXIII (1888), pp. 161-180. See also his Evolution and Ethics: The Romanes Lecture (London, 1893).

${ }_{78}$ Kropotkin, "The Ethical Need of the Present Day", p. 215.

"Kropotkin, "The Theory of Evolution and Mutual Aid", p. 86. 
accepted as a probable theory". ${ }^{80}$ Though Darwin had "felt a sort of paternal predilection for his hypothesis" he had not been prepared to defend it in the face of contrary evidence. ${ }^{81}$ Specifically, Kropotkin claimed, Darwin had come to accept that natural selection could not explain species variability. He had even retreated from the idea of individual chance variation, accepting that variation affected groups and did so in a "directed [. . . ] proper, necessary way" by the direct action of the environment. ${ }^{82}$

Kropotkin's ability to demonstrate Darwin's acceptance of Lamarckian theory was crucial. It not only enabled him to purge Darwinian theory of its Malthusian influence but also to counter Huxley's separation of natural and ethical development with his own view of a unified progression. ${ }^{83}$ If nature was not as the "Malthusian" theory of natural selection described, then mutual aid could provide a foundation for ethics.

Only too aware of the importance of demonstrating his point Kropotkin proceeded stubbornly to defend Lamarckian principles in the face of contrary scientific evidence. In particular he attacked Weismann who had demonstrated that acquired characters could not be inherited and had thus undermined the idea that environmental factors could explain evolutionary progression. Weismann had also put forward an explanatory thesis of "germ transmission" which, by hypothesizing the existence of an internal mechanism of inheritance, bolstered the neoDarwinian defence of natural selection. ${ }^{84}$ Whilst Kropotkin acknowledged the persuasiveness of Weismann's findings, he did not flinch in his determination to defend Lamarck. ${ }^{\text {s }}$

Against Huxley's "narrow" conception of struggle Kropotkin expounded two senses of mutual aid: one biological, the other ethical. Biologically, mutual aid was an instinctual sense of co-operation. Ethical mutual aid, on the other hand, was created by the habits which result from biological practice. By co-operating, species formulate codes of behaviour, languages and a sense of common interest. As they work together they alter the conditions of their material life and by changing their environment they in turn become transformed. Since it operates by the direct action of the environment, ethical mutual aid may be encouraged or inhibited in its development by particular historical circumstances. Where material conditions have been altered according to

${ }^{1}$ Ibid. p. 89.

1 lbid., p. 90.

lbid., p. 98.

"See Kropotkin, "The Direct Action of Environment and Evolution", p. 89.

" See Kropotkin, "The Inheritance of Acquired Characters", "Inherited Variation in Animals" and "The Direct Action of Environment and Evolution".

is Kropotkin's discussion of Lamarckianism extended into his "Recent Science" series for The Nineteenth Century. See especially his articles in vol. XXXII (1892), pp. 1007-1014; vol. XXXV (1894), pp. 684-691; and vol. L (1901), pp. 423-438. 
the principles of mutual aid, species make further ethical progress. Alternatively, where conditions inhibit co-operation; species regress. In Mutual Aid and The State: Its Historic Role, Kropotkin sought to show this in an anthropological and historical account of human society. Following nineteenth-century practice he charted the human development through three stages: savagery, barbarism and civilization. Mutual aid had achieved its highest form at the start of the final stage, in the period of the medieval city state, but the establishment of the centralized state since then had inhibited its further expression.

Huxley's mistake, Kropotkin argued, was that by limiting his research to a study of the natural world he had ignored this developmental aspect. He had erroneously identified the contingent conditions of the bourgeois liberal state as a necessary outcome of a universal law of natural development. But restoring the study of nature to its rightful place in the study of society, Kropotkin argued, pointed to a different conclusion: society should be restructured by rebuilding those residual forms of organization which had been suppressed by the modern state. In short, the reunification of natural and human science led to the conclusion that the proper organization of society was anarchy.

Kropotkin's critique of Huxley focused his work on the unity of human and natural sciences. He further developed this unification in his last work Ethics, published posthumously in 1921. Here, following J.-M. Guyau, he argued for a conception of morality "without obligation or sanction". But going beyond Guyau's work, Kropotkin also attempted to show that the basis of this morality was in mutual aid. In Ethics, Kropotkin divides theorists, from the Greeks to Spencer, into two major categories: metaphysicians and natural scientists. In line with this distinction he judges the work of both groups in two ways. Firstly, he examines each theorist's comprehension of the "essence of ethics" which he defines, not surprisingly, as the development of mutual aid. Secondly, he examines each theorist's contribution to the "general movement of ethics" - a movement liberating ethics from religion and intuition. Metaphysicians, he argues, have generally understood the essence of ethics but have failed fully to comprehend its movement. Natural scientists, by contrast, have understood the movement of ethics, but have failed to comprehend its essence. Using the insights of the metaphysicians Kropotkin concludes that morality lies in the "greatest happiness of society". Unfortunately, he admits, there is no consensus among political theorists on what constitutes social happiness and the formulation "taken by itself, is too abstract, too remote and would not be able to create moral habits and a moral mode of thought". ${ }^{86}$ Religion, he concedes, once provided a foundation for ethics, but the proofs of the natural scientists have turned ethics against religion and made science its appro-

${ }^{86}$ Kropotkin, Ethics, pp, 334-335. 
priate modern substitute. His conclusion is that metaphysical and scientific understanding can only be united in the theory of mutual aid.

\section{SCIENCE AND ANARCHY}

How does all this relate to Kropotkin's political campaign? Kropotkin did not imagine he could "convert" the opposition to anarchism by the theory of mutual aid. He only wanted to show that there was an alternative to what he saw as the two prevailing currents of ideas: Marxism and Nietzscheanism. Mutual aid was meant to strengthen the appeal of anarchism amongst those workers who, whilst unconvinced by "authoritarianism" and "individualism", were powerless to resist them effectively. Kropotkin saw the theory of mutual aid as a means to keep the anarchist tendency alive in a period of revolutionary quiescence. As he explained a year before his death:

I have undertaken to write on Ethics because I regard that work as absolutely necessary. I know well that intellectual movements are not created by books, and that just the reverse is true. But I also know that for clarifying an idea the help of a book is needed, a book that expresses the bases of thought in their complete form. ${ }^{87}$

For all his passionate interest in science, therefore, Kropotkin's political aim was paramount. He was always concerned to find politically useful examples of mutual aid. In 1895, for example, he confided to Max Nettlau his desire "to show the incredible [. . .] amount of mutual aid support among workers, as manifested during strikes" and asked him to help find "some information about the miseries, the suffering of the workers [...] to show by a few abstracts from facts [.. .] what workers must suffer each time they resort to a strike".88 As Malatesta rightly points out, Kropotkin used scientific theory "to support his social aspirations". ${ }^{89}$ This was particularly true as he expanded mutual aid into an ethical theory. As he remarked to Guillaume,

Tu avais vu, par Mutual Aid, et tu verras par State: Its Historic Role quel formidable, puissante instrument d'investigation présente l'inspiration anarchiste l'hypothèse anarchiste en parlant le langage de la science [...]

Et - plus que cela. Sans le principle d'entr'aide - enfant légitime de l'anarchie il n'y a pas moyen de construire l'Ethique. ${ }^{90}$

Tropotkin to Alexandre Atabekian, quoted in Woodcock, Ethics, p. xvii.

Kropotkin to Nettlau, 28 November 1895, IISH, Nettlau Collection, 287, KI.

Errico Malatesta, "Peter Kropotkin - Recollections and Criticisms of an Old Friend", The Raven, 5:4 (1992), p. 399.

${ }^{90}$ Kropotkin to Guillaume, 12 June 1903. "You have seen, with Mfutual Aid, and you will see with The State: Its Historic Role what a remarkable, powerful tool of investigation the anarchist tendency represents - the anarchist hypothesis in the language of science [...] And - more than that. Without the principle of mutual aid - the legitimate child of anarchy there is no means of building an Ethics". 
With politics in mind, Kropotkin directed the theory of mutual aid against the twin threat of Marxism and Nietzscheanism. In the former case, it allowed him to broaden and formalize his critique. Kropotkin rejected Marxism because he believed it attempted to show an inevitable process of change, through unalterable stages of development working independently of human will. But not only was it based on unscientific speculation, it was, as he again told Guillaume, authoritarian:

Ce n'est pas seulement parce que les uns [the Marxists] sont des métaphysiciens et les autres [the anarchists] - les gens de science. Il y a plus. Leur métaphysique est autoritaire. Ils sont métaphysiciens, parce qu'ils veulent l'autorité, et se réservent une place parmi ceux qui gouvernent. ${ }^{91}$

In the theory of mutual aid Kropotkin reinforced his critique of Marxism in two ways. On the one hand, he met the Marxists' claim to have discovered the principles of "scientific" socialism by contrasting his own "inductive-deductive" conception of change to Marx's "metaphysical" theory. On the other, he countered the notion of a necessary law of revolutionary development by showing that evolutionary progression demanded active intervention. Here, Kropotkin relied heavily on his critique of Weismann's theory of "germ transmission". This theory, he argued, was deficient both because it was based on the dialectical method $^{92}$ and because Weismann accepted the idea that "evolution without a teleological guidance from above was an unscientific conception". In the end, the theory of "germ transmission" was like Marxism, a child of Hegel. Weismann, Kropotkin charged,

came to the conclusion that, although evolution is a mechanical process, it must have been predetermined by a supreme power in accordance with a certain plan. And, in order to "reconcile teleology with mechanism", he borrowed [...] the idea of "continuity" of the germ-plasm; and thus he came to a Hegelian conception of an "immortal germ-plasm" - a "matter endowed with an immortal soul". ${ }^{93}$

Using his defence of Lamarck against Weismann, Kropotkin argued that changes in the environment, and principally in economic organization, led to ethical changes, which could in turn prompt further material alterations. But none of these developments was inevitable. Indeed, it was precisely by showing that evolutionary development might be regressive and that ethical progress was not guaranteed, that Kropotkin sought to counter the passivity he had criticized in Marxism and to build into his theory an incentive for action. Since the study of nature taught that "everything changes [... ] everything is incessantly modified" it also pointed to the conclusion that the world "we see around us is only a

'Kropotkin to Guillaume, 12 June 1903.

92 Kropotkin to Herzig, 29 April 1911, IISH, Herzig Collection; Kropotkin to Guillaume, 17 March 1903, IISH, Nettlau Collection, 293, KVI.

${ }^{93}$ Kropotkin, "The Direct Action of the Environment and Evolution", p. 75. 
passing phenomenon which ought to be modified [. . .] because immobility would be death".94

Kropotkin's critique of the other threat, Nietzscheanism, was more directly related to his attack on Huxley. For Kropotkin, Huxley's "Christian" morality had, paradoxically, opened the door to Nietzschean atheist individualism. Huxley, he argued, was one of a number of writers "proclaiming faith as the very source of all true knowledge". And it was in the context of this general return to religion that the success of Nietzscheanism could be understood. It was religion which had provoked the "revival of that worship of 'superior natures', now invested with the names of 'supermen', or 'superior individualisations', which Europe had lived through in the times of Byronism and early Romanticism". ${ }^{95}$ Kropotkin believed that Nietzsche had gone too far in denying the existence of moral truth and sought to counter this by providing a foundation for moral action. This emerges clearly in a letter to Guillaume:

Pour ma part j'y vois dans cette Entr'aide, tracée jusqu'aux animaux inférieurs, ou plutôt depuis les animaux inférieurs jusqu'à nous, j'y vois les plus athée des arguments anti-religeux. Il chasse le neo-darwinisme de son dernière refuge l'éthique chretienne - en lui disant "morale christianisme n'a rien enseigné que les fourmis n'eussent pratique dans l'entr'aide", lorsqu'ils parlaient d'aimer son voisin; et en parlent d'amour, au lieu de solidarite, il n'a fait qu'ouvrer la porte à l'individualisme le plus enragé.\%

By countering what he saw as Nietzsche's rejection of morality, Kropotkin hoped that anarchists would act on their passions, without falling into indiscriminate violence. Following Guyau, he wanted to encourage the idea that human life was about "risk" and self-sacrifice in the face of evil. He wanted to show that the moral sense came from within individuals, rather than without. ${ }^{97}$ Yet he sought to limit the range of possible actions by suggesting that ethical action was rooted in mutual aid. Treading this thin line, he drew a distinction between legitimate terrorist acts, performed in a "spirit of revolt" and illegitimate acts of "propaganda by the deed"..$^{98}$ Although the distinction between permissible and impermissible action appears to be a faint one, for

24 Kropotkin, Revolutionary Studies (London, 1892), pp. 9-10.

${ }^{95}$ Kropotkin, "The Ethical Need of the Present Day", p. 213.

\% Kropotkin to Guillaume, 23 December 1902. "For my part, I see in Mutual Aid, traced back to the lower animals, or rather from the lower animals to us, I see the most atheistic of anti-religious arguments. It drives neo-Darwinism from its last refuge - Christian ethics by stating that 'Christian morality has taught us nothing that could not be learnt from ants practising mutual aid', when they talked of loving one's neighbour; and in talking of love instead of solidarity, it has only opened the door to the most insane kind of individualism."

7 Kropotkin, Ethics, pp. 322-332.

9 See Kropotkin to Herzig, 9 March 1909, IISH, Herzig Collection, on the republication in 1909 of "Propaganda Par Le Fait" in Le Reveil. Kropotkin attributes the article to Paul Brousse and draws an explicit contrast between its message and that contained in his own "L'esprit de rEvolte". 
Kropotkin it was fundamental - no less than the difference between scientific and "individualist" ethics: the first recognized the needs and aspirations of the community, the other served only the needs of the individual. A knowledge of the theory of mutual aid would not impose sanctions or obligations on anarchists but it would put them in touch with the natural anarchist tendencies of the masses and would teach them to tailor their actions to its movements.

\section{CONCLUSION}

This paper has argued that Kropotkin's theory of mutual aid can usefully be seen as an attempt to revitalize the anarchist movement; in particular it has focused on its function in countering what Kropotkin saw as the dual threat of Marxism and Nietzschean individualism. Although Kropotkin's work has undeniable links both with the prevailing positivism of the age and with dominant trends in Russian biology, in the end his polemics against Huxley and his use of Darwinian theory were tailored to meet his political concerns. "Scientific research", he once wrote, "is only fruitful on condition that it has a definite aim - that it is undertaken with the intention of finding an answer to a plain question well put." Kropotkin's own "plain question" was: how could a form of social life be found which guaranteed humanity the greatest happiness? Even before embarking on the theory of mutual aid, he had a good idea of the answer. Society, he believed, was "tending" towards anarchy. In the theory of mutual aid, Kropotkin confidently asserted that scientific research provided conclusive evidence for this belief. Consequently, he argued, the duty of the anarchist was to "help evolution in this direction". ${ }^{100}$

Kropotkin cannot be said to have had a naive and optimistic belief in inevitable progress or to have assumed that evolutionary change was equivalent to progress. Whilst he identified mutual aid as the dominant factor in evolution, he did not exclude the possibility that other factors, like "struggle", could lead to regression. He simply suggested that real human progress depended on the expression of mutual aid. For Kropotkin, "the relative amounts of individualist and mutual aid spirit are among the most changeable features of man". ${ }^{101}$ Environmental changes could at any time alter circumstances to favour one over the other.

Seen in relation to the international state system, apparently moving towards war, the theory of mutual aid suggested that whilst Europe might have fallen under the influence of Teutonic authoritarianism,

\footnotetext{
99 Kropotkin, Modern Science, p. 41.

${ }^{200}$ Ibid., p. 45.

${ }^{101}$ Kropotkin, "Proposed Communist Settlement: A New Colony for Tyneside or Wearside", Newcastle Daily Chronicle, 20 February 1895.
} 
progress was still possible. In this context, the theory of mutual aid was intended to help sustain the anarchist movement in a period of doldrums until it was strong enough to destroy the state system. In the long term, Kropotkin never doubted that the expression of mutual aid would entail a violent rupture with the existing system. Indeed, the lesson of nature was that "[p]eriods of very slow changes are succeeded by periods of violent changes". ${ }^{102}$ It was this sense of necessary conflict that fuelled his concern that anarchists act with moral correctness when that violence came.

The theory of mutual aid, therefore, was intended as both a scientific explanation of change and an educative tract. And in the end, there is tension between these two aims. After all, if environmental change is itself sufficient to release mankind's latent spirit of mutual aid why is there any need to demonstrate that this tendency is scientific? Kropotkin's answer might be that the demonstration was necessary in order to ensure that anarchists both continued the struggle in a reactionary period and acted morally. But this answer in turn risks admitting that anarchism might not be a natural tendency at all, merely one of several competing ideas to be instilled in the masses by the authority of science.

Kropotkin, Revolutionary Studies (London, 1892), p. 9. 